\title{
Vector Error Correction Model on FDI and their Impact in the Republic of Macedonia
}

\author{
Irena Kikerkova* \\ Elena Naumovska \\ Katerina Toshevska-Trpchevska * \\ Elena Makrevska Disoska*
}

\begin{abstract}
The subject of this paper is the foreign direct investment (FDI) inflow in Macedonia and its impact upon the economic growth and development of the country. Its basic purpose is to analyse the interconnection of FDI with a number of economic, political and institutional variables in Macedonia. We decided to apply Vector Error Correction Model (VECM) on FDI impact upon the Macedonian economy. The FDI indicator is calculated as a function of certain fundamental economic variables (GDP growth rate, labor productivity rate, openness to trade, current account balance) as well as of Worldwide Governance Indicators (control of corruption, government effectiveness, political stability, regulatory quality and rule of law). Results obtained by the econometric model should provide relevant conclusions on the impact of the up-to-date FDI inflow upon the growth and development of the Macedonian economy.
\end{abstract}

Keywords: foreign direct investment; Technological Industrial Development Zones (TIDZ); economic and institutional variables; Vector Error Correction Model; Republic of Macedonia

\section{JEL Classification: $F 21$}

\section{Introduction}

FDI and its motivation throughout different geographic regions in the world was extensively examined and explained in the economic theory in the last three decades. This was also the case with the so called transition economies where through different models and quantitative equasions the economists tried to measure the impact

\footnotetext{
* Irena Kikerkova, Katerina Toshevska-Trpchevska and Elena Makrevska Disoska are at Ss. Cyril and Methodius University, Faculty of Economics-Skopje, Skopje, Republic of Macedonia.
} 
that FDI have or might create upon their sucessful restructuring and further economic growth.

Authorities in Macedonia also spent a lot of time in creating and implementing different strategies on FDI trying to attract the attention of foreign investors to the opportunities that the country offered them. All of them, and especially the last implemented strategy based on creation of Technological Development Industrial Zones (TIDZ) as an exclusion of the regular customs and tax territory were rather disputable in terms of the cost-benefit analysis. This issue, as well as the fact that up to our knowledge there is no model on FDI created for analytical purposes in the country was the main motivation for our effort on pursuing the research presented in this paper. The analysis in the paper starts with an overview of relevant theories on FDI with special emphasize on research effectuated in transition economies. The next chapter deals with the available statistical data on FDI inflows in Western Balkan countries. The paper continues with a presentation of actual legal framework on FDI in Macedonia pointing out to the regulative and incentives for foreign investors provided by the Law on Technological Industrial Development Zones. Also relevant statistical data on foreign direct investment inflows, their origin by greatest foreign investors and their sector distribution in Macedonia will be provided. The main contribution of the paper is the application of VECM (Vector Error Correction Model) on foreign direct investment impact upon the economy. Results obtained by the econometric model should provide relevant conclusions on the impact of the up-to-date FDI inflow upon the growth and development of the Macedonian economy.

\section{Brief Overview on Relevant Theory on FDI}

Economic thought has always served as a "mirror" reflecting different phases of economic growth and development. Many times contradictory stand points of different economic theories were resolved by economic growth itself. This statement also applies to the phenomena of the international movement of capital in the form of FDI. While economic thought tried and is still trying to explain the pros and cons of FDI, economic growth undoubtedly confirmed that they are a crucial feature of the contemporary global world and essential for further economic development.

The abundant economic literature on FDI comprises a vast number of different theories created in the period from the appearance of the classical economic school until the development of the latest new trade theories.

Classical theory did not integrate the free movement of capital in the international trade theory (Bastable, 1897).

The neoclassical concept, however, acknowledges that by exporting the capital the exporter gets incorporated in the global production which enables him to secure 
not only important markets (Kikerkova, 1998). Followers of the Keynesian economic model also believed that the outflow of capital from the national economy was dictated by the disequilibrium within the balance of payments (Machlup, 1965 and Harrod, 1939).

During the 1970's the economic thought focused on explaining FDI motivation from the position of the model of imperfect competition on the world market. Following the flows of capital on the relation among developed economies, the creators of this concept claimed that FDI had exceptional positive influence upon the economic growth of both the home and the host economy and especially stressed advantages realized by spill-overs of knowledge and managerial skills (Kindelberger, Ch. P. \& Andretsch, D.B., 1983, and Vernon, 1979). Later on, this concept was extended and developing countries were involved in further research as well and theoreticians claimed that this would lead to the same positive effects upon the economic growth for their economies as well.

The contemporary concepts on FDI were mostly influenced by Dunning's $O L I$ Paradigm (Dunning 1988) and Porter's Diamond of Competitive Advantages (Porter, 2000). While within the OLI Paradigm the outflow of capital is still an alternative to export of goods, in Porter's theory both of the flows have to continue simultaneously as they are not substitutes or alternatives to each other in the contemporary global environment. In 1993 Dunnig and Rojec accepted Porter' theory and upgraded it pointing out that FDI support not only the economic growth and development of the home country, but also could support the wellbeing and growth of the host country. They were among the first who applied this model upon the transition economies and related the inflow of FDI with the opportunity of increasing productivity in manufacturing industries that already existed in those countries; the opportunity of bringing innovations and improvements of the existing productions, processes and organizational structures; the promotion of new allocation of recourses among different sectors; the opportunity to get access to new markets; and the acceleration of structural changes within the economy and decrement of costs needed for technological changes (Dunning \& Rojec, 1993).

Lately there is a considerable number of theories that refer to the influence of market growth and the openness of the economy upon the inflow of FDI (Deichman et al, 2003; Asiedu, 2006; Mohamed and Sidiropulus, 2010). Yet, these theories did not provide any reliable proof that the mentioned determinants are significantly important for attracting FDI.

From the stand point of the transition economies, we believe that it is important to mention theories on the institutional framework and its influence upon the attractiveness for FDI. The institutional approach refers to the level of institutional reforms that influence the quality of institutions. Institutional reforms should provide tools for fighting corruption and political instability as they both degrade quality of institutions and prevent their development (Cleeve, 2008). 
This approach was further upgraded with research on the role of incentives in attracting FDI. Results of different researches made in this field were basically conflicting or with predominantly negative connotation. Most of the authors came to conclusion that the active approach in granting incentives to foreign investors might have strong negative impact upon the corruptive practices within the institutions of the system and might lead to withdrawal of the decision of a foreign investor to effectuate the investment. (Zemplinarova, 1996; Cleeve, 2008; Assunchao, S. et all, 2011). Abundant tax relieves usually have a negative impact on the total effect from the attracted FDI as they increase the costs for the host country to an extent that they might overcome the total positive effect of the effectuated foreign investment. It is even more important to point out that the up-to-date research in the area did not provide a proof on the statistically significant relation in attracting FDI neither with regard of institutional determinants nor in regard of financial and fiscal incentives (Assunchao et.all, 2011).

\section{FDI Indicators in Western Balkan Countries}

Due to political instability and the many war conflicts, the Western Balkan countries lost a whole decade in the '90's for macroeconomic stabilization, privatization and transformation of their systems towards a market economy. Since the beginning of the $21^{\text {st }}$ century the political and economic situation within these countries started to change gradually. In the period from 2001-2008 economic reforms and privatization process in the region started to accelerate and the region gradually liberalized trade, especially with the EU. All this led to substantial changes and improvement of the business climate in all of the countries throughout the region. Most of the economic reforms that were implemented in different WB countries relied on legal reforms in favor of FDI regime liberalization and pursued active policies on attracting the foreign investors' attention.

These efforts led to an increment of the total FDI inflow, which reached its peak in 2007, in the period of the beginning of the financial crises. The data in Graph 1 confirm that the crisis had strong negative impact upon the FDI inflow in WB countries and caused a decreament of almost $40 \%$ of net inflows on regional level by the end of 2009 in comparison to 2007. The recovery period lasted until 2013 when FDI inflow on regional level started to increase again. In comparison to 2004, by the end of 2016 the FDI net inflows as a percentage of GDP rose 4,12 percentage points in Albania, 2.29 percentage points in Serbia, 2.17 percentage points in Kosovo and 2.03 percentage points in Montenegro (calculated on basis of data in Graph 1). Although most of WB countries denote upward trends of the FDI indicator, the level of FDI net inflows as a percentage of GDP in 2016 is still lower than in 2004 on regional level. 
Graph 1: FDI net inflows /GDP in Western Balkan countries in the period from 2004 to 2016 (in \%)

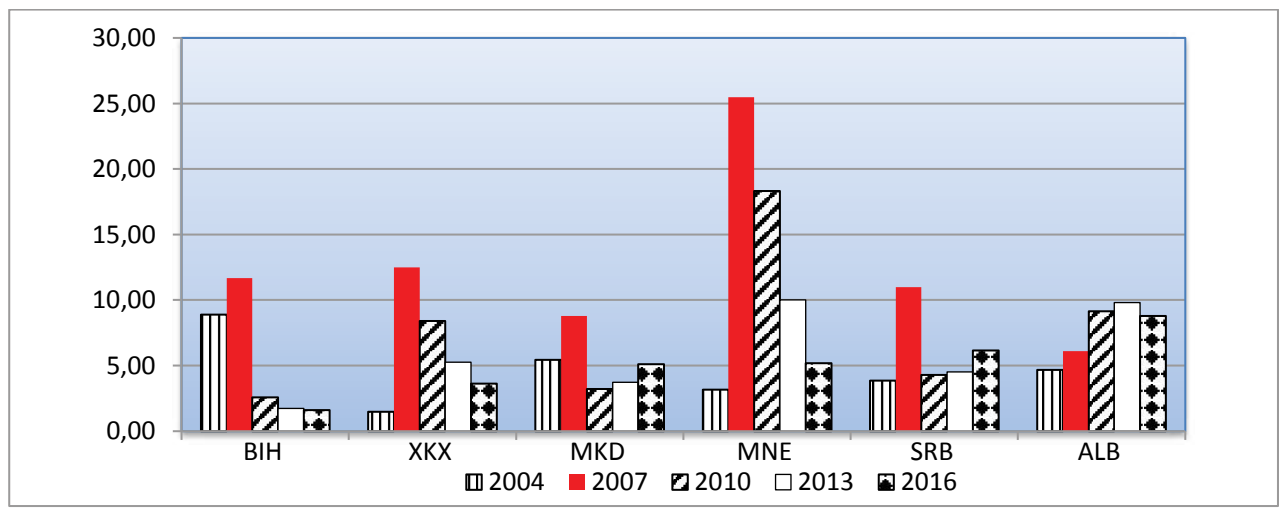

Source: World Development Indicators, World Databank

The slow-down in FDI inflow in the region was not caused only by the crisis, but generally it was a result of the completion of the privatization process and the lack of interest of foreign investors to invest in already existing enterprises. Foreign investors consider Serbia to be the country with the biggest capacity for attracting FDI within the region. However, Montenegro with 6.290 EUR per capita was the country with highest FDI stocks per capita in 2013 while Macedonia happens to be the least attractive country in the region (Pinto et al., 2016).

FDI net inflow within the region created about $8 \%$ of the total GDP on average. Although this indicator differs throughout the countries in the region, its average for the region as a whole is significantly above the results of the same indicator calculated for countries from Central and Eastern Europe where it reached 3\% of GDP.

In comparison to CEE countries, Western Balkan economies seem to be much more de-industrialized. In 2014 the average share of manufacturing value added in GDP for the Western Balkans was $12 \%$ while the average share of services was $62 \%$ of GDP. The de-industrialization happened basically as a result of loosing market access for manufactured products to traditional markets. This especially applies to economies that derived from the former Yugoslav state as they lost market access for their products within the region, within Eastern European countries which at that time had to deal with macroeconomic stabilization and transition programs of their own and within the EU where the preferential treatment for products with Yugoslavian origin was not applicable any more. 
Graph 2: FDI net inflows /GDP in Western Balkan Countries and CEE Countries in the period from 2004 to 2017 (in \%)

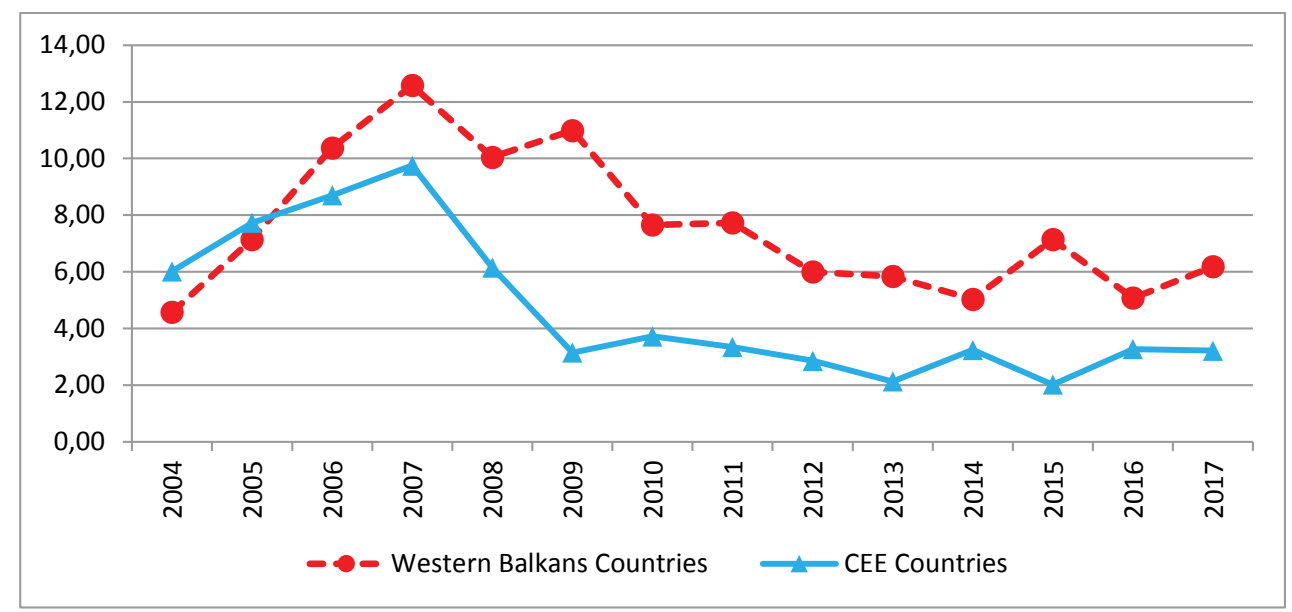

Source: World Development Indicators, World Databank

\section{Business Climate and FDI Inflow in Macedonia}

Macedonia registered a significant progress in improving its business climate in the last 10 years and according to World Bank's rankings it happens to be the best ranked country in the region.

The legal system underwent significant reforms providing liberal provisions on FDI and guaranteeing foreign investors national treatment. FDI legislation consists of number of different laws such as the Companies' Law, the Securities' Law, the Profit Tax Law, the Law on Personal Income Tax, the Law on Value Added Tax, the Law on Foreign Trade, the Law on Takeovers, the Law on Foreign Exchange, the Law on Investment Funds, the Banking Law, the Law on Supervision of Insurance, the Audit Law, etc. At present, the most influential enacted Law in the area is the Law on Technological Industrial Development Zones in 2008 (Official Gazette of the Republic of Macedonia No. 82/08). According to this Law, companies functioning within the TIDZ enjoy various customs and fiscal exemptions and reliefs as well as state subsidies for covering the costs for building plants, free construction licenses and free connection to water and gas pipe infrastructure. The government also provides subsides for creation of new working posts within the TIDZ, for covering costs of employees' trainings as well as exemptions from the employees' personal tax and from the payment of the corporate income tax. The most important incentives that the government provides for foreign investors in TIDZ are presented in Table 1. 
Table 1: Government incentives for foreign investors within the TIDZ

\begin{tabular}{|l|l|}
\hline Incentives in & - Providing construction land for the new plants under a 99 year concession; \\
infrastructure: & $\begin{array}{l}\text { - Free connection to the water and gas pipe infrastructure, free preparation of the } \\
\text { construction land and free construction licenses; } \\
\text { - Government participation in covering the building costs of new plants up to } \\
\text { - Tax exemptions for a 10-year period; }\end{array}$ \\
& $\begin{array}{l}\text { - } 0 \% \text { of VAT; } \\
\text { - } 0 \% \text { of Income Tax; }\end{array}$ \\
\hline State subventions in \\
cash:
\end{tabular}

Source: According to Official Gazette of the Republic of Macedonia. No. 82/08. 2008, p.

The reforms in the fiscal area and the approved tax incentives for foreign investors put Macedonia on the first place in the world taking in consideration the applied total tax rate in 2015. However according to last year's report of the European Commission, it seems that all the provisions regarding tax and customs exemptions as well as government's discretion rights in regard with the construction land are not in line either with the EU Code of Conduct for Business Taxation or with the European acquies (European Commission, 2015, p.).

Nevertheless, the FDI inflow in Macedonia during the last 15 years remained very low and created approximately $2.5-3 \%$ of the GDP per year. As a consequence of the economic crises in the EU, foreign investors started to withdraw money in the form of loans from their affiliations in the country. At the same time the amount of reinvested profit in the economy decreased substantially. Therefore, the amounts of outflow of capital were greater than the inflows of capital in the economy (Kikerkova 2013, p. 14).

Graph 3 points out to the changing structure in favor of green-field investment in comparison to acquisitions and mergers in Macedonia. This change was a result of the established TIDZ that managed to attract about 1.13 billion Euros of FDI in the form of green-field investment in the last 5 years. Up to 2011 green-field investment created slightly more than $38 \%$ while acquisitions and mergers created over $61 \%$ of the total amount of FDI in the country (National Bank of the Republic of Macedonia 2012, p.). 
Graph 3: Greenfield investment and acquisitions \& mergers in Macedonia in period from 1997 to 2015 (in EUR)

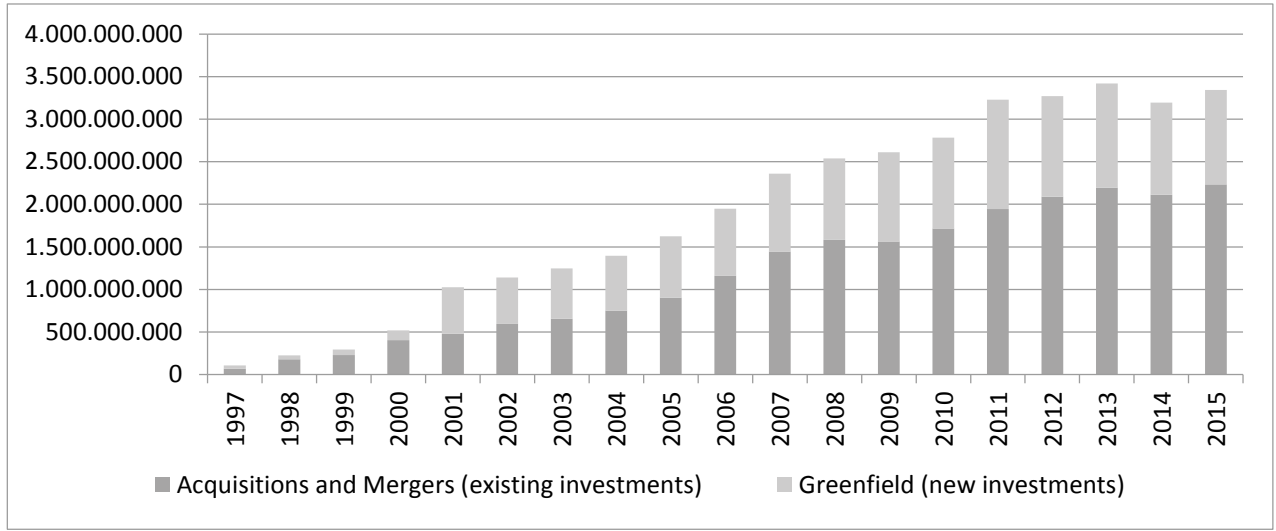

Source: The National Bank of the Republic of Macedonia

Graph 4: FDI economic structure in Macedonia in 2016 (millions of euro and \%)

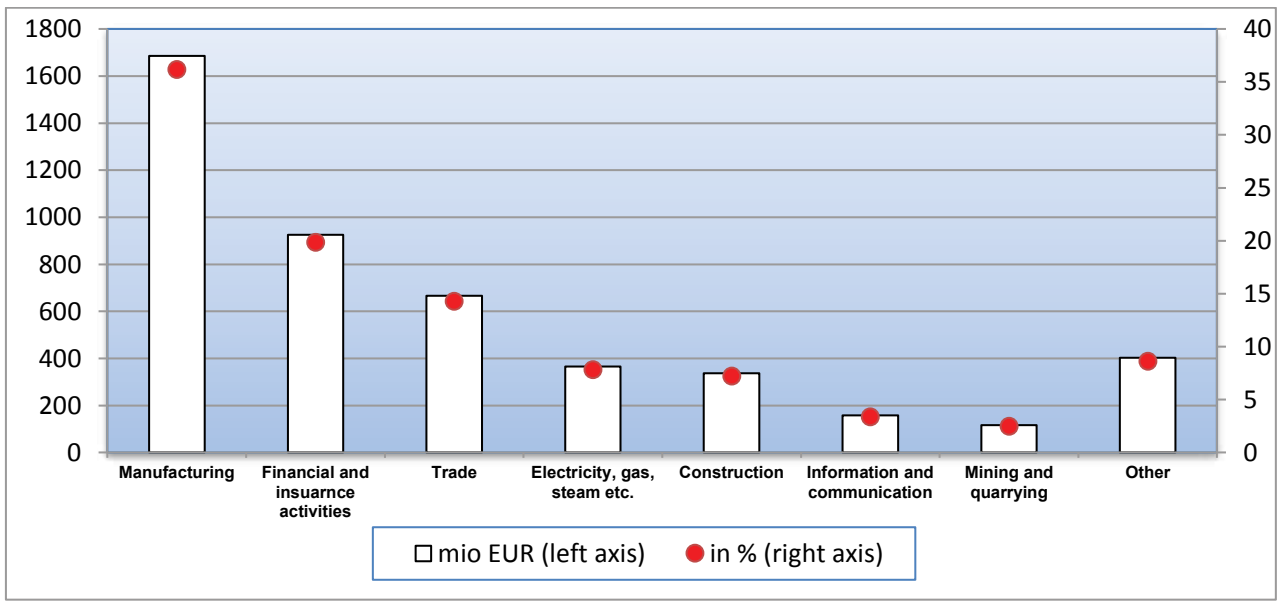

Source: The National Bank of the Republic of Macedonia

Statistical evidence of FDI confirms that up to 2009 services were slightly more attractive for foreign investors than the manufacturing sector which has been the actual trend in all of the WB countries. At the end of 2009 the services sector managed to attract 50\% of total FDI in Macedonia. In the last five years, the intensified investment in the TIDZ as well as in the regular customs area strengthened the position of the manufacturing sector, and within it the position of the chemical industry. Other important manufacturing sub-sectors in the country in regard with the inward FDI stocks are basic metals and fabricated metal products, food products, beverages and 
tobacco products, as well as motor vehicles, trailers and semitrailers (The National Bank of the Republic of Macedonia). Graph 4 points out the economic structure of FDI at the end of 2016 in the country.

The origin of invested FDI in the country has not changed significantly as over $90 \%$ of the invested FDI were form European countries. Data in Graph 5 present that the biggest amounts of FDI originated from Austria and Bermuda.

Graph 5: FDI by country of origin in Macedonia in 2015 (millions of euro)

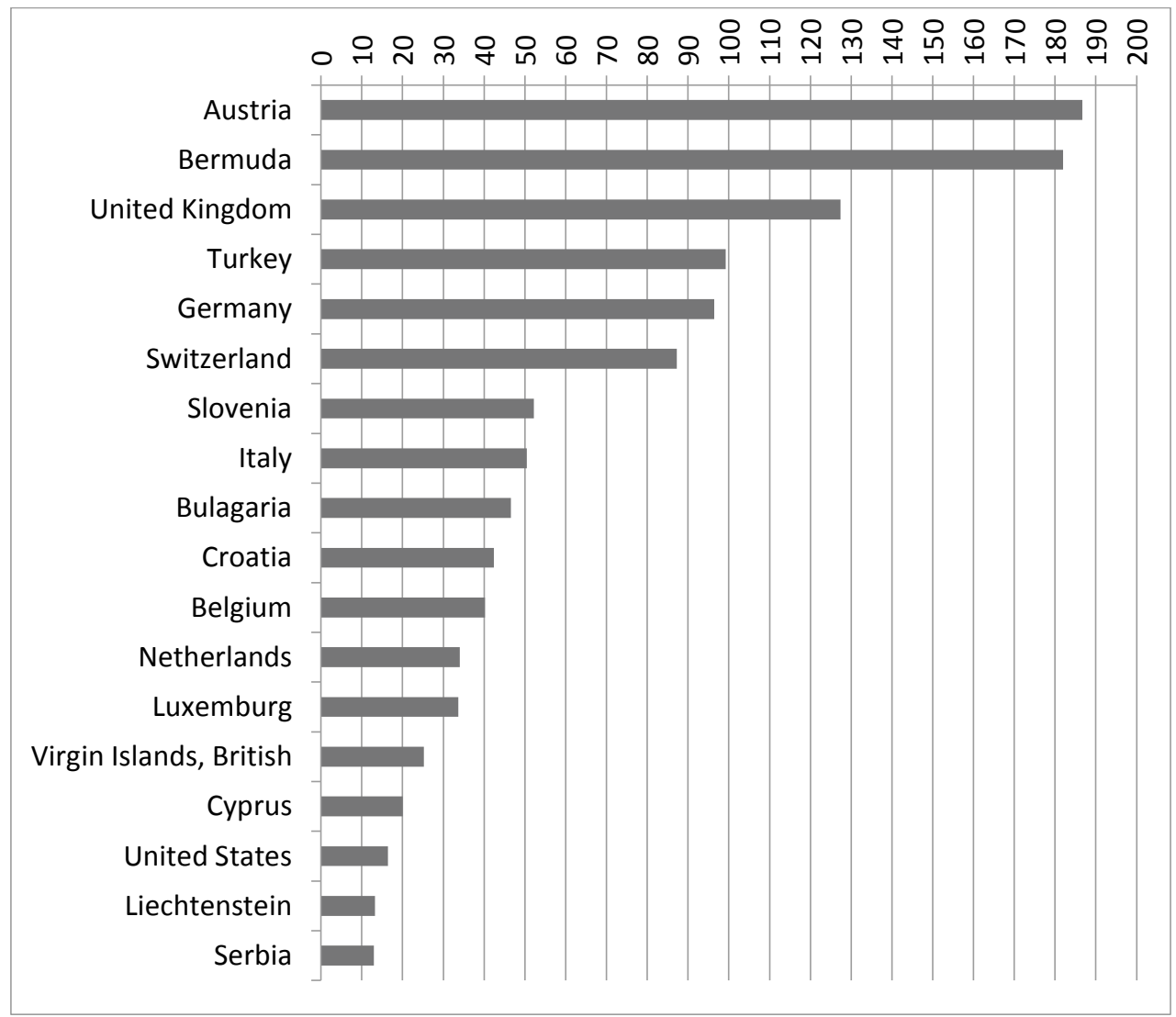

Source: The National Bank of the Republic of Macedonia

\section{The Long-run Trend of the FDI/GDP Indicator in Macedonia}

This section represents a statistical analysis of the long-run trend of the FDI inflow/ GDP indicator as well as an econometric estimation of this indicator related to certain economic, political and institutional variables in Macedonia. 


\section{Specification of Variables and Creating a Model}

In our analysis the variables that have a potential connection with FDI inflows are divided into two categories. The first category is represented by endogenous variables with a potentially mutual connection with FDI. It consists of the following set of economic variables: economic growth, labor productivity, openness to trade and current account balance. We have used quarterly data for a period of 13 years (from the first quarter of 2003 to the fourth quarter of 2015) obtained from the National Bank of the Republic of Macedonia and the State Statistical Office of the Republic of Macedonia. The second category is represented by exogenous (political and institutional) variables with potential influence only in the direction from those variables to foreign investment inflows and not vice versa. These variables are calculated as indexes based on yearly data obtained from the World Bank, World Governance Indicator database for the period from 2003 to 2015.

Table 3 presents the specification of endogenous (2-5) and exogenous variables (67) included in the econometric model andtheir signs, calculation, source and results expected for each variable.

Table 3: Endogenous and exogenous variables taken into account

\begin{tabular}{|l|l|l|l|l|c|}
\hline & \multicolumn{1}{|c|}{ Variable } & \multicolumn{1}{|c|}{ Sign } & \multicolumn{1}{|c|}{ Calculation } & Source & Expected sign \\
\hline 1 & $\begin{array}{l}\text { Foreign direct } \\
\text { investment inflow }\end{array}$ & FDI & FDI inflow/GDP & NBRM & + \\
\hline 2 & Economic growth & GDPG & Real GDP growth rate & NBRM & + \\
\hline 3 & Trade openness & OPEN & (Export + Import)/GDP & NBRM & + \\
\hline 4 & Labor productivity & LABPRD & GDP per employee (rate of growth) & NBRM & + \\
\hline 5 & $\begin{array}{l}\text { Current account } \\
\text { balance }\end{array}$ & BP & Current account balance/ GDP & NBRM & + \\
\hline 6 & $\begin{array}{l}\text { Index of institutional } \\
\text { factors }\end{array}$ & INSTIT & $\begin{array}{l}\text { Calculated as Index based on } \\
\text { Corruption and Rule of law percentile } \\
\text { rank for a country }\end{array}$ & $\begin{array}{l}\text { Governance } \\
\text { Indicator, } \\
\text { World Bank }\end{array}$ & + \\
\hline 7 & $\begin{array}{l}\text { Index of political } \\
\text { factors }\end{array}$ & POLICY & $\begin{array}{l}\text { Calculated as Index based on Political } \\
\text { stability, Government Effectiveness } \\
\text { and Regulatory Quality percentile } \\
\text { rank for a country }\end{array}$ & $\begin{array}{l}\text { World } \\
\text { Governance } \\
\text { Indicator, } \\
\text { World Bank }\end{array}$ & + \\
\hline
\end{tabular}

A simple statistical approach provides an opportunity to obtain certain information and warnings and draw some conclusions. However, these findings need to be further tested and validated by applying more complex models and methods. The econometric approach tries to explain the level of FDI inflows as a function of certain economic, political and institutional variables. 
The FDI/GDP ratio is calculated as a function of certain fundamental variables and the "normal value" of this ratio is assessed. For this purpose, we have used VECM (the Vector Error Correction Model) in the following form:

$$
\Delta Y_{t}=\mu_{1}+C X+A \Delta Y_{t-1}+\alpha\left[\begin{array}{l}
\beta 1 \\
\mu 2
\end{array}\right] Y_{t-1}+\omega_{t}
$$

Where $Y$ denotes the vector of endogenous variables (FDI, GDPG, BP, LABPRD, OPEN), $X$ denotes the vector of exogenous variables (POLICY, INSTIT), $\mu_{l}$ is an unrestricted intercept in the error correction model, $A$ is a matrix of coefficients measuring short-run effects of endogenous variables, $C$ is a matrix of coefficients measuring short-run effects of exogenous variables, $\alpha$ is a matrix of coefficients measuring speed of adjustment to equilibrium, $\beta_{l}$ denotes the matrix of long-run coefficients, $\mu_{2}$ is the restricted intercept in the cointegrating vector and $\omega$ is the error term.

In order to investigate the possibility of non - stationarity in the dataset, we used Augmented Dickey Fuller test for stationarity, and the results of the unit root test showed non - stationarity in the endogenous variables. To check the validity of the VECM model we did a few diagnostic tests and found that the residuals of the regressions have normal distribution and do not show any auto - correlation.

Table 1 (Appendix) presents the descriptive statistics of both the endogenous and exogenous variables of the model. It demonstrates the mean, median, maximum, minimum, standard deviations as well as skewness and kurtosis values of the $52 \mathrm{ob}-$ servations associated with each of the 7 variables used in the study. According to the information criterion in the Table 2 (Appendix), especially SC (Schwarz information criterion) and HQ (Hannan-Quinn information criterion) based on unrestricted VAR, the number of lags in the model should be one.

\section{Presentation of Results}

Table 5 presents the long-run relations and their significance between the FDI indicator and other economic, political and institutional variables as well as the coefficients measuring the speed of adjustment. 
Table 5: Estimation of the model co-integration equation

\begin{tabular}{|l|c|c|c|c|}
\hline \multicolumn{1}{|c|}{ Variable } & Coefficient & t-statistic & \multicolumn{2}{c|}{$\begin{array}{c}\text { Speed of adjustment } \\
\text { Coeficient }\end{array}$} \\
\hline FDI & 1 & $/$ & -0.030 & -0.026685 \\
\hline GDPG & 1.072 & $2.49731^{*}$ & -0.295 & $-3.37052^{*}$ \\
\hline OPEN & 0.967 & $6.00903 *$ & -0.559 & $-3.28439 *$ \\
\hline LABPRD & 0.551 & $1.97861^{* *}$ & -0.383 & $-3.87033^{*}$ \\
\hline BP & -0.136 & $-1.46816^{* * *}$ & 0.302 & $1.83712^{* * *}$ \\
\hline POLICY & 0.149 & 0.72078 & $/$ & $/$ \\
\hline INSTITUT & $-0,204$ & -1.05004 & $/$ & $/$ \\
\hline $\begin{array}{l}\text { Note: } \\
* \text { means level of significance of } 1 \%, \\
* * \text { means level of significance of } 5 \%, \\
* * * \text { means level of significance of } 10 \%\end{array}$ & & & \\
\hline
\end{tabular}

According to the results obtained, there is a long-run relationship between endogenous (economic) variables and the FDI indicator with different levels of significance for each variable. The highest level of significance of $1 \%$ is found for the long-term relationship between FDI on one side and economic growth and openness to trade, on another side. The level of significance of the labor productivity long-term parameter is 5\% while the current account balance parameter has the lowest level of significance of $10 \%$. Additionally, there is an insignificant long-term influence of the political and institutional variables on FDI inflows. According to the results obtained, we can conclude that economic factors (primarily the ability to generate higher profits, openness to trade and the cheap skilled labor force) constitute leading factors for investing in Macedonia.

The long- run parameter of the economic growth (GDPG) is positive and highly significant, showing that if real GDP growth rate increases by 1 percentage point, then the FDI inflows as a percent of GDP will increase on average by 1.07 percentage points, assuming all other factors unchanged. Moreover, this positive relation is in accordance with our initial expectations and it has credible theoretical background by its own definition. As a rule, the market size has a positive relation with FDI which means that a larger market and a market that is increasingly growing will receive larger inflows of FDI. On the other hand, growth enhancing the acceleration of FDI inflow suggests that the increase in FDI causes a positive reaction to the economic growth in Macedonia.

With regard to the openness of the economy (OPEN), a positive and highly significant long-run relation has been obtained, showing that if trade openness indicator increases by 1 percentage point, then the FDI inflows as a percent of GDP will increase on average by 0.97 percentage points in the long run, assuming all other factors unchanged. The research points to the importance of an open economy for 
attracting FDI. This is in accordance with our initial expectations and is also found in some previous empirical studies. Countries that want to attract more FDI ought to increase foreign trade exchange as well (Aiedu, 2006). At the same time, some empirical studies (Aiedu, 2006; Vijayakumar et al. 2010) argue that countries which receive less FDI would be more attractive if they implemented reforms that liberalize their economies.

The labor productivity (LABPRD) long-run parameter is positive and significant with a lower level of significance of 5\%, which shows that if the labor productivity increases by 1 percentage point, then the FDI indicator will increase on average by 0.55 percentage points in the long run, assuming all other factors unchanged. Given the growth rate of labor productivity is increasing the amount of GDP per employee we can conclude that attractiveness for investment in Macedonia is increasing with the ability to generate more revenue per employee. Taking into consideration that FDI enable the creation of new jobs, productivity growth would mean faster GDP growth relative to the increase in number of employees. On the other hand, as a result of FDI, application of modern technology and know-how is expected which would in turn encourage the growth of productivity. Even though the result was in line with our initial expectations and theoretical background in mind, it is necessary to take into account the fact that the relationship is at a lower level of significance of $5 \%$ and this long-term placement of parameters is not as pronounced in this respect, so it is necessary to take into account the fact that in many cases foreign investors create jobs by employing workers who were already employed in domestic companies. In this case of unchanged number of employments, the state faces higher costs due to its state tax incentives and education for the newly employed.

The long-run parameter of the current account balance (BP) is negative and with a weak level of significance of $10 \%$, showing that if BP as a percent of GDP increases by 1 percentage point, then the FDI inflows as a percent of GDP will decrease on average by 0.14 percentage points in the long run, assuming all other factors unchanged. The inverse relation is a result of the FDI inflow influences in reducing the current account balance of payment's deficit. This is in accordance with the NBRM paper analyzing the effects of companies' activity in TIDZ on the balance of payments of the Republic of Macedonia where it is stated that the operation of new companies improved (narrowed) the current account deficit by an average of 0.3 percentage points of GDP in the past seven years. Namely, the average current account deficit in the period 2009-2015 amounted to 2.6\% of GDP, whereas if the activity of the new companies was excluded it would be $3.0 \%$ of GDP. The dynamic analysis of the current account deficit is a useful explanation of our results relating to the weak significance between FDI and current account balance showing that the effect of TIDZ in the first five-year period is generally small and such dynamics of the current account balance results from higher initial import of equipment and materials at the time of founding the new facilities and the initial investment cycle. More significant 
effects were registered in the last two years when the effect on the deficit contributed to narrowing the negative gap in the current account.

If we look at the institutional and political variables with potential influence on FDI separately, we can consider that the Index of Political Factors (POLICY) based on Political Stability, Government Effectiveness and Regulatory Quality percentile ranks for a country, has a positive relation with the FDI indicator. This index captures the perceptions of the ability of the government to formulate and implement sound policies and regulations, the quality of public services, the degree of independence from political pressures, as well as the likelihood of political instability. Hence, greater government credibility and political stability have greater potential to accelerate the FDI inflow in the country.

The Index of Institutional Factors (INSTITUT) is calculated as an index based on the Corruption Percentile Rank for a country (captures the perceptions of the extent to which public power is exercised for private gain) and the Rule of law percentile rank for a country (captures the perceptions of the extent to which agents have confidence in the quality of contract enforcement, property rights, the police and the courts). According to the results obtained, there is an inverse insignificant influence of the index of institutional factors on FDI in Macedonia. The inverse relation between FDI and institutional factors may indicate that the lack of transparency, low quality of contract enforcement, insufficient control of corruption and inefficient courts may attract more FDI inflows as a result of greater opportunity for profit generation in a country with lower levels of institutional regulation.

Regarding the coefficients measuring the speed of adjustment, the cointegrating vector enters three equations with level of significance of $1 \%$ and one equation with level of significance of $10 \%$. In the equation where the changes of real GDP growth is the dependent variable, the adjustment coefficient is statisticaly significant with the appropriate sign and indicates that if real GDP growth is above its long-run equilibrium level, the deviation will be offset such that 29.5 percent of the remaining disequilibrium is accomplished in each successive quarter by a decrease of real GDP growth, which implies a period of 5 quarters for around 80 percent of the total adjustment required to take place via changes in the real GDP growth alone. In the equation where the changes of openness of the economy is the dependent variable, the adjustment coefficient is statisticaly significant with the appropriate sign and indicates that if openness of the economy is above its long-run equilibrium level, the deviation will be offset such that 55.9 percent of the remaining disequilibrium is accomplished in each successive quarter by a decrease of openness of the economy, which implies a period of 3 quarters for around 90 percent of the total adjustment required to take place via changes in the openness of the economy alone. In the equation where the changes of labor productivity is the dependent variable, the adjustment coefficient is statisticaly significant with the appropriate sign and indicates that if labor productivity is above its long-run equilibrium level, the deviation will be offset such that 38.3 
percent of the remaining disequilibrium is accomplished in each successive quarter by a decrease of labor productivity, which implies a period of 5 quarters for around 90 percent of the total adjustment required to take place via changes in the labor productivity alone. In the equation where the changes of the current account balance is the dependent variable the coefficient of speed of adjustment is significant (at $10 \%$ level of significance) and positive indicating that the divergence from the equilibrium in the current quater is restored by $30.2 \%$ in the previous quarter.

\section{Conclusion}

Having in mind the theoretical background on FDI, and the available statistical data, we decided to test some endogenous and exogenous variables in the case of Macedonia in a VECM. The set of endogenous variables consists of the following economic variables: economic growth, labor productivity, openness to trade and current account balance. The exogenous political and institutional variables are considered only in regard with their one way potential influence in direction from those variables to foreign investment inflows, and not vice versa.

According to the results obtained, we can conclude that economic factors (primarily the rate of GDP growth, openness to trade and labor productivity) constitute leading factors for investing in Macedonia. The positive relation between the rate of GDP growth and the FDI inflows is highly expected and credible. The relationship is positive in both directions, as higher GDP can lead to higher FDI inflows, as well as, the increase in FDI can cause positive reaction to the economic growth in the country. The dynamic analysis of the current account deficit confirmed that the effect of TIDZ in the first five-year period is generally small and as such results from higher initial import of equipment and materials at the time of founding the new facilities and the initial investment cycle, while more significant effects were registered in the last two years, when the effect on the deficit contributed to narrowing the negative gap in the current account. Considering the relation in regard of availability of cheap labor, in many cases in Macedonia foreign investors create jobs by employing workers who were already employed in domestic companies which makes tax incentives and costs on education for the newly employed highly expensive and ineffective. At the same time, it is questionable if such reduced revenues and increased costs for the state would positively influence a higher GDP growth than they would affect certain capital expenditures of the state which as productive investments would have a greater effect on stimulating the economic growth.

In the case of exogenous variables greater government credibility and political stability happen to be essential for attraction of greater FDI inflow in the country. According to the results obtained, there is an inverse insignificant influence of the index of institutional factors on FDI in Macedonia. This may indicate that the lack of 
transparency, low quality of contract enforcement, insufficient control of corruption and inefficient courts may attract more FDI inflows as a result of greater opportunity for profit generation in a country with lower levels of institutional regulation.

\section{APPENDIX}

Table 1. Descriptive statistics parameters

\begin{tabular}{|l|c|c|c|c|c|c|c|}
\hline & FDI & GDPG & BP & LABPRD & OPEN & POLICY & INSTITUTIONAL \\
\hline Mean & 3.8 & 3.4 & -4.1 & 1.7 & 98.3 & 47.1 & 47.6 \\
\hline Median & 2.6 & 3.4 & -3.8 & 0.5 & 103.6 & 46.8 & 51.7 \\
\hline Maximum & 21.4 & 10.7 & 7.2 & 12.6 & 120.0 & 61.0 & 57.9 \\
\hline Minimum & -1.1 & -3.7 & -21.1 & -10.5 & 67.5 & 36.5 & 32.4 \\
\hline Std. Dev. & 3.7 & 3.7 & 6.4 & 5.1 & 15.1 & 6.4 & 7.4 \\
\hline Skewness & 2.3 & 0.2 & -0.7 & 0.2 & -0.4 & 0.2 & -0.6 \\
\hline Kurtosis & 11.0 & 2.2 & 3.6 & 2.9 & 2.0 & 3.0 & 2.2 \\
\hline Observations & 52 & 52 & 52 & 52 & 52 & 52 & 52 \\
\hline
\end{tabular}

Table 2. The number of lags in the model

VAR Lag Order Selection Criteria

Endogenous variables: FDI GDPG BP LABPRD OPEN

Exogenous variables: C POLICY INSTITUTIONAL

Sample: 2003Q1 2015Q4

Included observations: 48

\begin{tabular}{|c|c|c|c|c|c|c|}
\hline Lag & LogL & LR & FPE & AIC & SC & HQ \\
\hline 0 & -527.9205 & NA & 69274.48 & 22.49669 & 22.96449 & 22.67347 \\
\hline 1 & -491.1196 & 62.86813 & $29344.33 *$ & 21.62999 & $22.72152^{*}$ & $22.04248^{*}$ \\
\hline 2 & -477.4098 & 21.13605 & 33091.90 & 21.72541 & 23.44067 & 22.37361 \\
\hline 3 & -464.2882 & 18.04221 & 39353.52 & 21.84534 & 24.18434 & 22.72925 \\
\hline 4 & -439.8703 & $29.50489 *$ & 30516.08 & $21.49460 *$ & 24.45733 & 22.61422 \\
\hline \multicolumn{7}{|c|}{$*$ indicates lag order selected by criterion } \\
\hline
\end{tabular}

\section{REFERENCES}

Asiedu, E. (2006). Foreign direct investment in Africa: The role of natural resources, market size, government policy, institutions and political instability. World Economy, 29 (1), 63-77. DOI: $10.1111 / \mathrm{j} .1467-9701.2006 .00758 . x$

Assunchao, S., Forte, R., \& Teixeira, A. A. (2011). Location determinants of FDI: a literature review (No. 433). Porto: Universidade do Porto, Faculdade de Economia do Porto.

Bastable, C. F. (1897). The theory of international trade: with some of its applications to economic policy. London: Macmillan \& Company, limited. 
Cleeve, E. (2008). How effective are fiscal incentives to attract FDI to Sub-Saharan Africa? The Journal of Developing Areas, 42(1), 135-153. DOI: 10.1353/jda.0.0015

Deichmann, J. I., Eshghi, A., Haughton, D. M., Ayek, S., \& Teebagy, N. C. (2003). Foreign direct investment in the Eurasian transition states. Eastern European Economics, 41(1), 5-34.

Dunning, J. H. (1988). The eclectic paradigm of international production: A restatement and some possible extensions. Journal of international business studies, 19(1): 1-31.

Dunning, J.H. \& Rojec, M. (1993). Foreign Privatization in Central and Eastern Europe. Ljubljana: Central and Eastern European Privatization Network.

European Commission. (2015). The former Yugoslav Republic of Macedonia Report 2015. Brussels: European Commission, Working Document 10.11.2015 SWD (2015) 212 final.

Harrod, R. F. (1939). An essay in dynamic theory. The economic journal, 49(193), 14-33.

Kikerkova, I. (1998). Foreign Direct Investment in Transition Economies - with a special outlook of the Republic of Macedonia. Skopje: University Ss. Cyril and Methodius, Faculty of Economics - Skopje (in Macedonian).

Kikerkova, I. (2013). Empirical Evidence on Foreign Direct Investment Impact upon the Economic Growth of the Republic of Macedonia. Scientific Conference on Innovative Approaches to the Contemporary Economic Problems, 27-29 September (p.14) Dubrovnik, Croatia: University of Dubrovnik, Department of Economics and Business Economics.

Kindelberger, Ch. P. \& Andretsch, D.B. (1983). The Multinational Corporations in the 1980's. Cambridge: MIT Press.

Machlup, F. (1965). International Trade and the National Income Multiplier. New York: Augustus M. Kelley bookseller.

Mohamed, S. E., \& Sidiropoulos, M. G. (2010). Another look at the determinants of foreign direct investment in MENA countries: an empirical investigation. Journal of economic development, 35(2), 75.

Official Gazette of the Republic of Macedonia No. 82/08, Skopje, 2008.

Porter, M. (2000). The Competitive Advantage of Nations. The Free Press: New York

Zemplinarova, A. (1996): Incentives and Disincentives for FDI in Transition Economies, Prague: Economic Institute of the Academy of Sciences.

Vernon, R. (1979). The product cycle hypothesis in a new international environment. Oxford bulletin of economics and statistics, 41(4), 255-267.

\section{INTERNET PAGES}

www.nbrm.mk

www.statistics.gov.mk

The World Bank. Doing Business. Accessed April 2016

http://www.doingbusiness.org/reports/global-reports/doing-business-20156.

The World Economic Forum. Global Competitiveness Report. Accessed April 2016. http://www.weforum.org/reports/global-competitiveness-report-2014-2015. 